\title{
Molecular basis of bone morphogenetic protein-4 inhibitory action on progesterone secretion by ovine granulosa cells
}

\author{
A Pierre, C Pisselet, J Dupont, B Mandon-Pépin1, D Monniaux, P Monget and \\ S Fabre
}

Physiologie de la Reproduction et des Comportements, UMR 6175 INRA-CNRS-Université de Tours, Haras Nationaux, 37380 Nouzilly, France

1Biologie du Développement et de la Reproduction, UMR 1198 INRA-ENVA, 78350 Jouy en Josas, France

(Requests for offprints should be addressed to S Fabre; Email: sfabre@tours.inra.fr)

\begin{abstract}
We have recently reported that bone morphogenetic protein-4 (BMP-4) can inhibit progesterone production by ovine granulosa cells (GCs). Here, we have investigated the underlying mechanisms of this effect in basal as well as in FSH-induced conditions. We have confirmed that treatment with BMP-4 decreased basal GC progesterone secretion and totally abolished FSH-stimulating action. This inhibitory action was associated with a decrease in the expression of cAMP-regulated genes, steroidogenic acute regulatory protein (StAR) and P450 side-chain cleavage (P450 scc) at mRNA and protein levels. However, BMP-4 did not alter basal cAMP production by GCs. In contrast, BMP-4 decreased by half the FSH-induced CAMP production and strongly inhibited CAMP-induced progesterone production. Thus, the inhibitory effect of BMP-4 was exerted both upstream and downstream of cAMP signalling. We next examined the downstream effect, focusing on CAMP-dependent transcription factors, steroidogenic factor-1 (SF-1) and CREB, through the BMP factor signalling intermediary, Smad1. As expected, BMP-4 induced phosphorylation and transcriptional activity of Smad1 in ovine GCs. BMP-4-activated Smad1 did not affect CREB activity but inhibited the transcriptional activity of SF-1 on the canonical SF-1 responsive element. Interestingly, this transcriptional inhibitory mechanism occurred on transfected StAR and P450 scc promoter. Based on these results, we propose that SF-1 is a key target in the inhibitory mechanism exerted by BMP-4 on progesterone synthesis by ovine GCs in culture. Because SF-1 plays an essential role in the differentiation of GCs, our findings could have new implications in understanding the role of BMP family members in the control of ovarian folliculogenesis.
\end{abstract}

Journal of Molecular Endocrinology (2004) 33, 805-817

\section{Introduction}

Follicle-stimulating hormone (FSH) plays a central role in ovarian folliculogenesis, particularly in regulating granulosa cell $(\mathrm{GC})$ differentiation. In particular, FSH enhances the expression of steroidogenic enzymes such as cytochrome P450 side-chain cleavage (P450 scc) and P450 aromatase (Richards \& Hedin 1988, Winters et al. 1998) and these actions are importantly modulated by various growth factors, acting in a paracrine or autocrine way (Khamsi et al. 2001). From recent accumulating in vivo and in vitro evidence, it appears that members of the bone morphogenetic protein
(BMP) family of cytokines and their receptors are strongly implicated in ovarian function, controlling folliculogenesis and ovulation rate (Monget et al. 2002). A study of invalidated mice for growth and differentiation factor-9 (GDF-9), an oocyte-derived growth factor of the BMP family, has shown that this factor is required during early ovarian folliculogenesis enabling primordial and primary to secondary follicle transition (Dong et al. 1996). In sheep, two loss of function mutations in the gene encoding BMP-15, another oocyte-derived factor closely related to GDF-9, have been shown to be responsible for a strong alteration of follicular growth in a dose-dependent manner. An increase 
in ovulation rate was observed in the heterozygous carrier Inverdale and Hanna ewes, the homozygous being sterile (Galloway et al. 2000). Moreover, it has been shown that a substitutive mutation (Q249R) in the gene encoding BMP receptor (BMPR)-1B (also called Alk6), one of the type-1 receptors triggering the BMP intracellular signalling, is responsible for an increase in ovulation rate (threefold in heterozygous carrier ewes and more than fivefold in homozygous carriers) in the Booroola strain (Mulsant et al. 2001, Souza et al. 2001, Wilson et al. 2001).

In vitro, recombinant BMP-4, BMP-6, BMP-7, BMP-15 and GDF-9 are able to strongly inhibit FSH-induced progesterone secretion by rat GGs in culture (Shimasaki et al. 1999, Otsuka et al. 2000, 2001a,b, Vitt et al. 2000, Lee et al. 2001, Souza et al. 2001). In contrast, BMP-4 and BMP-7 enhance FSH-dependent estradiol production, suggesting that BMP factors regulate GC differentiation, particularly in delaying the luteinization process (Shimasaki et al. 1999).

Several studies in the rat and the ewe using in situ hybridization or immunohistochemistry have detected the expression of several elements of the BMP signalling pathway in the ovary. For example, BMP-4 and BMP-7 are expressed by theca cells (Shimasaki et al. 1999), whereas BMP-6, GDF-9 and BMP-15 are oocyte-derived factors (for review, Elvin et al. 2000). BMP type I receptors, BMPRIA/Alk3 and BMPR1B/Alk6 and type II receptor BMPRII are expressed in GCs and oocytes (Shimasaki et al. 1999, Wilson et al. 2001, Souza et al. 2002). Transducing molecules of the Smad family have been detected in all compartments of follicles in the rat ovary (Drummond et al. 2002, Xu et al. 2002). Altogether, these observations indicate the presence of a complete BMP signalling pathway in ovaries, enabling autocrine and paracrine regulation.

Less is known about the mode of action of BMP family members on target cells in the ovary, particularly in GCs. In the rat, most actions of the BMP molecules on GC steroidogenesis are FSH dependent. The proposed mechanism of action implicates down-regulation of FSH receptor expression or decrease in adenylate cyclase activity (Otsuka et al. 2001a,b). In contrast, we have recently demonstrated that BMP-4, a known ligand of Alk6, inhibits progesterone secretion by ovine GGs in the absence of FSH (Mulsant et al. 2001, Fabre et al.
2003). However, the precise intracellular mechanism that underlies the inhibiting action of BMP-4 has not been determined.

In the present study, we have investigated the mechanism of action by which BMP-4 exerts an inhibitory action on basal as well as FSH-induced progesterone secretion through modulation of the cAMP signalling pathway and expression of genes involved in steroidogenesis. We propose that BMP-4 modulates progesterone by inhibiting the steroidogenic factor-1 (SF-1) transcriptional activity on steroidogenic gene promoters. In FSH-induced conditions, this mechanism might be reinforced by an inhibition of adenylate cyclase activity.

\section{Materials and methods}

\section{Reagents and supplies}

Fluorogestone acetate sponges used to synchronize oestrous cycles were obtained from Intervet (Angers, France). Porcine FSH (pFSH) from pituitary extracts ( $\mathrm{pFSH}$ activity $=1 \cdot 15$ times the activity of NIH pFSH-P1) used for injections to animals was obtained from Dr Y Combarnous (Nouzilly, France). Purified ovine FSH-20 (oFSH) (lot no. AFP-7028D; $4453 \mathrm{IU} / \mathrm{mg} ; \mathrm{FSH}$ activity $=175$ times the activity of oFSH-S1) used for culture treatment was a gift from the NIDDK (National Hormone Pituitary Program, Bethesda, MD, USA). Recombinant human FSH (rhFSH) used in adenylate cyclase activity experiments was obtained from Serono (Boulogne, France). Recombinant human BMP-4 was obtained from R\&D Systems Europe (Lille, France). DibutyrylcyclicAMP (db-cAMP) and isobutyl methylxanthine (IBMX) were purchased from Sigma (L'Isle d'Abeau Chesnes, France). Rabbit polyclonal anti-Smadl and anti-phospho-Smadl were obtained from Upstate Biotechnology (Euromedex, Mundolsheim, France). Rabbit polyclonal antiP450 scc antibody was purchased from Chemicon (Euromedex, Mundolsheim, France). Rabbit polyclonal antibody raised against human placental $3 \beta$-hydroxysteroid dehydrogenase $(3 \beta$-HSD) and mouse steroidogenic acute regulatory protein (StAR) were kindly provided by Dr V Luu-The (Quebec, Canada) and Dr D B Hales (Chicago, IL, USA) respectively.

Plasmid designated pSG-SF1, constructed by inserting cDNA encoding the murine SF-1 into 
pSG5 vector (Stratagene, Amsterdam, The Netherlands) and pGL3 TkLH $\beta$, a luciferase reporter gene under the control of two copies of the SF-1-responsive element of the luteinizing hormone $(\mathrm{LH})-\beta$ promoter gene, were a gift from $\mathrm{Dr} A$ Martinez (Val et al. 2003). Plasmid pf-Smad1, constructed by inserting a flag-tagged murine Smadl into pcdef3 vector was kindly provided by Dr M Kawabata (Ishida et al. 2000). Plasmid Gal4-tk80-luc was a luciferase reporter gene under the control of the Gal4-responsive element and plasmid pGal4-Smadl was a human Smadl sequence fused with the DNA-binding domain of Gal4 (Pearson et al. 1999). P450 scc luciferase reporter constructs containing fragments of the human P450 scc gene spanning from nucleotides -110 to +49 , with or without the mutated SF-1-binding site, subcloned in pGL3 vector, were kindly provided by Dr B Staels (Gizard et al. 2002). StAR luciferase reporter construct containing fragments of human StAR gene spanning nucleotides -235 to +39 was a gift from Dr J Strauss (Sugawara et al. 1996). The cAMP-sensitive reporter construct of the somatostatin gene promoter (pSOM-luc) was kindly provided by Dr B Peers (Liège, Belgium).

\section{Animals}

Fifty adult cyclic Romanov ewes were treated with intravaginal sponges impregnated with progestagen (fluorogestone acetate, $40 \mathrm{mg}$ ) for 15 days to mimic a luteal phase. Ovaries were collected from animals in the luteal phase of the oestrous cycle (10 days after sponge removal), stimulated by intramuscular injections of $6 \mathrm{IU}$ and $5 \mathrm{IU}$ pFSH administered $24 \mathrm{~h}$ and $12 \mathrm{~h}$ prior to slaughter respectively. All procedures were approved by the Agricultural and Scientific Research Government committees in accordance with the guidelines for the Care and Use of Agricultural Animals in Agricultural Research and Teaching (approval A37801).

\section{Isolation and culture of GCs}

Briefly, in each independent culture experiment, ovarian follicles from three to four Romanov ewes were quickly dissected, pooled and classified according to size. GCs were recovered from small antral follicles (1-3 $\mathrm{mm}$ in diameter) as previously described (Le Bellego et al. 2002). For progesterone and cAMP production, GC suspensions were seeded at 100000 viable cells/well in 96-well plates and cultured for $144 \mathrm{~h}$ at $37^{\circ} \mathrm{C}$ with $5 \% \mathrm{CO}_{2}$ in serum-free McCoy's 5a medium (Sigma) according to a previously described method (Campbell et al. 1996). Cultures were performed with or without different exogenous factors (BMP-4, oFSH, dbcAMP or IBMX), each alone or in combination. Each combination of treatments was tested in triplicate in at least four independent culture experiments. Culture media were partially replaced (180 over $250 \mu \mathrm{l})$ at $72 \mathrm{~h}$. Media conditioned between 72 and $144 \mathrm{~h}$ of culture were collected at $144 \mathrm{~h}$ and stored at $-20{ }^{\circ} \mathrm{C}$ prior to radioimmunoassays. At the end of the culture, the number of cells per well was estimated after trypsinization by counting an aliquot of each resulting cell suspension with a haemacytometer under a phase contrast microscope.

Alternatively, for phospho-Smadl detection or transient transfection experiments, GGs were cultured in McCoy's 5a medium supplemented with $3 \%$ fetal ovine serum during the $72 \mathrm{~h}$ prior to specific treatments.

\section{Northern blot analysis}

For RNA blot analysis, GGs were harvested $72 \mathrm{~h}$ after treatment with oFSH $(5 \mathrm{ng} / \mathrm{ml})$ or BMP-4 $(50 \mathrm{ng} / \mathrm{ml})$ alone or in combination, and total RNAs were isolated using Rnable solution (Eurobio, Les Ulis, France). Twenty micrograms of total RNAs were separated by denaturing formaldehyde electrophoresis, then transferred to a nylon membrane by capillary action overnight and immobilized by exposure to u.v. light. Blots were prehybridized for $2 \mathrm{~h}$ at $42{ }^{\circ} \mathrm{C}$ in a buffer containing $50 \%$ formamide, $5 \times$ Denhardt's, $1 \%$ SDS, $5 \times \mathrm{SSC}$ and $100 \mu \mathrm{g} / \mathrm{ml}$ denatured salmon sperm. The probes were labelled using the Rediprime labelling kit (Amersham Pharmacia Biotech, Orsay, France). cDNA probes for ovine StAR, P450 scc and $3 \beta$-HSD were generated by RT-PCR on ovine whole follicle mRNA using the following primers: StAR sense 5'-GGTGCT GAGTAAAGTGATCG-3' and StAR antisense 5'-CATGTGCTGGTAGAGTGTGG-3'; P450 scc sense 5'-CTCTTTAAGTTCGAGGGATC-3' and P450 scc antisense 5'-TCACTTTGAGGGTAT CTCTG-3'; 3 $\beta$-HSD sense 5'-CACATTCTGGC CTTGAGGGG-3' and 3 $\beta$-HSD antisense 5'-CAG 
GAAGCGAAGCAGAAAAC-3'. The radioactivity was quantified using a STORM apparatus and ImageQuant software (Amersham Pharmacia Biotech). The integrity and the quantification of different transcripts were assessed using the human RNA 18S probe as a control (Ambion, Huntingdon, Cambs, UK).

\section{Western blot analysis}

GC whole cell extracts were obtained by resuspension in lysis buffer $(10 \mathrm{mM}$ Tris, $\mathrm{pH} 7 \cdot 4,150 \mathrm{mM}$ $\mathrm{NaCl}, 1 \mathrm{mM}$ EDTA, $1 \mathrm{mM}$ EGTA and $0.5 \%$ Igepal) containing several protease inhibitors (2 $\mathrm{mM}$ phenylmethylsulphonyl fluoride, $10 \mathrm{mg} / \mathrm{ml}$ leupeptin and $10 \mathrm{mg} / \mathrm{ml}$ aprotinin) and phosphatase inhibitors $(100 \mathrm{mM}$ sodium fluoride, $10 \mathrm{mM}$ sodium pyrophosphate and $2 \mathrm{mM}$ sodium orthovanadate (Sigma)). Lysates were centrifuged at $15000 \boldsymbol{g}$ for $20 \mathrm{~min}$ at $4{ }^{\circ} \mathrm{C}$, and the protein concentration in the supernatants was determined by a colorimetric assay (BC Assay kit; Uptima Interchim, Montluçon, France). The protein samples $(30-60 \mu \mathrm{g})$ were fractionated using SDSPAGE in $12 \%$ polyacrylamide gels and transferred to nitrocellulose membranes (Schleicher \& Schuell, Ecquevilly, France). For steroidogenic protein detection, GGs were harvested after $144 \mathrm{~h}$ of treatment with FSH and/or BMP-4 in serum-free condition. The same samples were run and transferred on three independent membranes to allow individual detection of P450 scc and 3 $\beta$-HSD and dual detection on the same membrane of StAR and actin was used as a loading control. Proteins of the steroidogenic pathway were detected using rabbit polyclonal antibodies raised against StAR (1:500 final dilution), P450 scc (1:1000) and $3 \beta$-HSD (1:500). Actin was revealed using a mouse monoclonal anti-actin antibody (1:1000; Sigma). For Smadl detection, GGs were cultured for $72 \mathrm{~h}$ in McCoy's 5a medium supplemented with 3\% fetal ovine serum (500 000 cells/well; 6-well plate), then harvested after $48 \mathrm{~h}$ in serum-free condition before a 30-min stimulation with BMP-4 (50 ng/ $\mathrm{ml})$. Incubation with rabbit polyclonal or mouse monoclonal primary antibodies was followed by incubation with peroxidase-conjugated anti-rabbit IgG (1:20 000; Uptima Interchim) or with peroxidase-conjugated anti-mouse IgG (1:20 000; Bio-Rad, Marnes-la-Coquette, France) respectively.
Finally, the protein bands were detected using ECL detection reagents (Amersham Pharmacia Biotech).

\section{Assessment of progesterone and cAMP production}

The amount of progesterone (ng/50 000 cells) in the culture media conditioned between 72 and $144 \mathrm{~h}$ from each experiment was measured by radioimmunoassay as previously described (Saumande 1991).

For cAMP measurement, GCs from small antral follicles were cultured for $144 \mathrm{~h}$ with or without BMP-4 $(50 \mathrm{ng} / \mathrm{ml})$. At the end of the culture, media were removed and cells were stimulated for $2 \mathrm{~h}$ with $0.2 \mathrm{mM}$ IBMX in the presence or absence of $50 \mathrm{ng} / \mathrm{ml} \mathrm{rhFSH}$ in fresh McCoy's 5 a medium. Extracellular amounts of cAMP (pmol/50 000 cells) in the media conditioned during these last $2 \mathrm{~h}$ were measured using the cAMP radioimmunoassay kit (Perkin Elmer, Courtaboeuf, France) following the manufacturer's specifications. IBMX treatment was used to prevent the metabolic effect of phosphodiesterase on cAMP and then cAMP production was a direct measurement to adenylate cyclase activity.

\section{Transient transfection and luciferase assay}

GCs from small antral follicles were seeded at 200000 cells/well in 12-well plates and cultured for $72 \mathrm{~h}$ in McCoy's 5a medium supplemented with $3 \%$ fetal ovine serum. Then, the different plasmids expressing Smadl or SF-1 (500 ng/well) and luciferase reporter genes for Smadl or SF-1 activity $(1 \mu \mathrm{g} /$ well $)$ were transiently transfected to cells using DAC30 transfection reagent (Eurogentec, Seraing, Belgium) for $24 \mathrm{~h}$ with a DNA/DAC30 ratio of $1 / 2(\mathrm{w} / \mathrm{w})$ as specified by the manufacturer. After $24 \mathrm{~h}$, media were changed with fresh McCoy's 5a medium supplemented with $3 \%$ fetal ovine serum cells for an extra $24 \mathrm{~h}$ with or without BMP-4 (50 ng/ml) before luciferase assay (Promega, Charbonnières, France). Each combination of plasmids was tested in triplicate in each culture and in four independent experiments.

\section{Data analysis}

All experimental data are presented as means \pm S.E.M. The effects of hormones on progesterone secretion and cAMP production were 


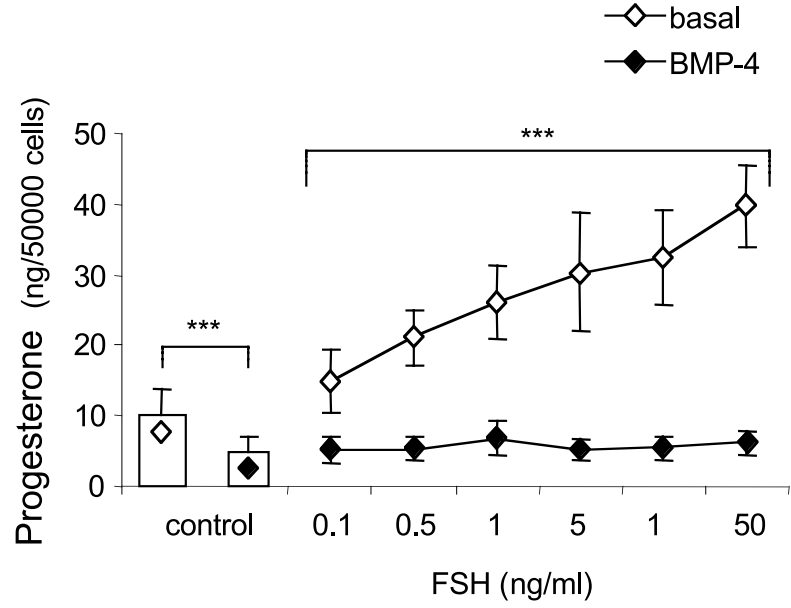

Figure 1 Effect of BMP-4 and FSH on progesterone production by primary ovine GCs in vitro. GCs from small antral follicles (1-3 $\mathrm{mm}$ in diameter) were cultured for $144 \mathrm{~h}$ in serum-free conditions with or without BMP-4 $(50 \mathrm{ng} / \mathrm{ml})$, in the absence (control) or the presence of increasing amounts of oFSH $(0.1-50 \mathrm{ng} / \mathrm{ml})$. Each combination of treatments was tested in triplicate in each of four independent experiments. Results represent progesterone secretion by 50000 GCs between 96 and $144 \mathrm{~h}$ of culture (means \pm S.E.M.). ${ }^{* *} P<0.001$, BMP-4 vs control in basal conditions. In FSH-induced conditions, for each dose used, BMP-4 significantly $(P<0.001)$ inhibited progesterone synthesis.

analyzed using two-way ANOVA in order to appreciate the 'hormone effect' as well as the 'culture effect'. For luciferase assays, data are expressed as relative to control condition. The effect of different combinations of plasmids was assessed by two-way ANOVA to allow for 'experiment effect' and 'plasmid effect' or 'BMP-4 effect'. One-way ANOVA was used to appreciate the treatment effect on Northern blot analysis. Post-hoc comparisons were performed with Scheffe's and Newman-Keuls tests. For all analyses, differences with $P>0.05$ were considered as not significant.

\section{Results}

\section{Effect of BMP-4 on basal and FSH-stimulated progesterone production by GCs}

As shown in Fig. 1, basal progesterone production between 72 and $144 \mathrm{~h}$ of culture was decreased by $57 \%(P<0 \cdot 001)$ by BMP-4. As expected, treatment with oFSH $\quad(0 \cdot 5-50 \mathrm{ng} / \mathrm{ml})$ dose-dependently increased progesterone production by GCs. In these FSH-stimulated conditions, the addition of BMP-4 totally abolished oFSH action $(P<0 \cdot 001)$. The same results were observed with GCs from preovulatory follicles $(5-6 \mathrm{~mm}$ in diameter) (data not shown).

\section{Effect of BMP-4 on steroidogenic enzyme genes}

In order to understand the inhibiting role of BMP-4 on GC progesterone production, we have studied the expression of genes implicated in progesterone synthesis, StAR, P450 scc and $3 \beta$-HSD, at mRNA and protein levels (Fig. 2). Northern blot analysis (Fig. 2A) showed a consistent decrease in StAR mRNA level after $72 \mathrm{~h}$ of BMP-4 treatment $(50 \mathrm{ng} / \mathrm{ml})$ in both basal $(P<0.05)$ and FSH-induced condition $(P<0 \cdot 01)$. Moreover, BMP-4 led to a decrease in P450 scc mRNA levels in FSH-induced condition only $(P<0 \cdot 05)$. In contrast, the $3 \beta$-HSD mRNA level was not clearly affected. This pattern of regulation on StAR, P450 scc and $3 \beta$-HSD mRNAs at $72 \mathrm{~h}$ was well correlated with the results observed for protein levels at $144 \mathrm{~h}$, as shown by Western blotting analysis (Fig. 2B).

\section{Effect of BMP-4 on cAMP production and activity}

The inhibitory effect of BMP-4 was investigated on the cAMP signalling pathway, a well-known regulator of steroidogenesis in GCs. After $144 \mathrm{~h}$ of culture, basal cAMP production of GGs, measured in the presence of IBMX, was not affected by BMP-4 treatment. In contrast, rhFSH-stimulated (50 $\mathrm{ng} / \mathrm{ml}$ ) cAMP production at the end of the culture was significantly reduced $(50 \%)$ by the presence of BMP-4 during the culture $(P<0 \cdot 001$; Fig. 3 left-hand panel). Moreover, BMP-4 strongly inhibited db-cAMP or IBMX stimulation of progesterone secretion (Fig. 3 right-hand panel). Together, these results indicated that BMP-4 could act negatively on both pre- and post-cAMP signalling events.

\section{Searching for the BMP-4 inhibitory mechanism}

Since basal and cAMP-dependent StAR, P450 scc and $3 \beta-H S D$ gene expression are regulated by a 
A

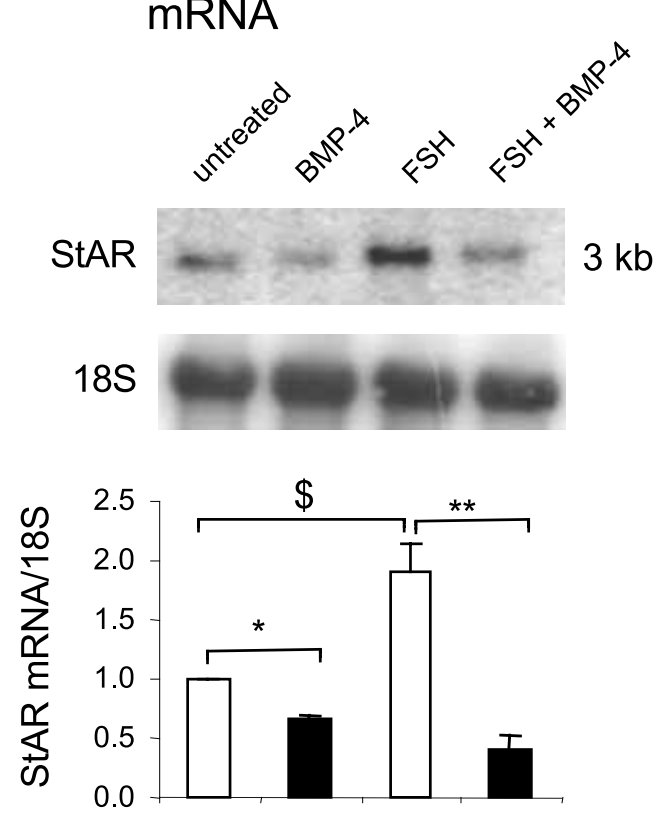

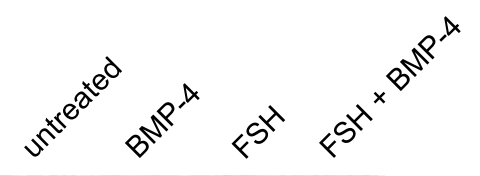

P450scc

$2 \mathrm{~kb}$

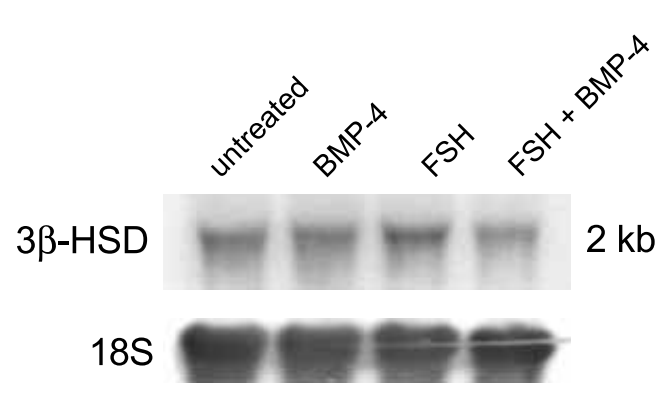

B

\section{Proteins}

\section{$18 S$}
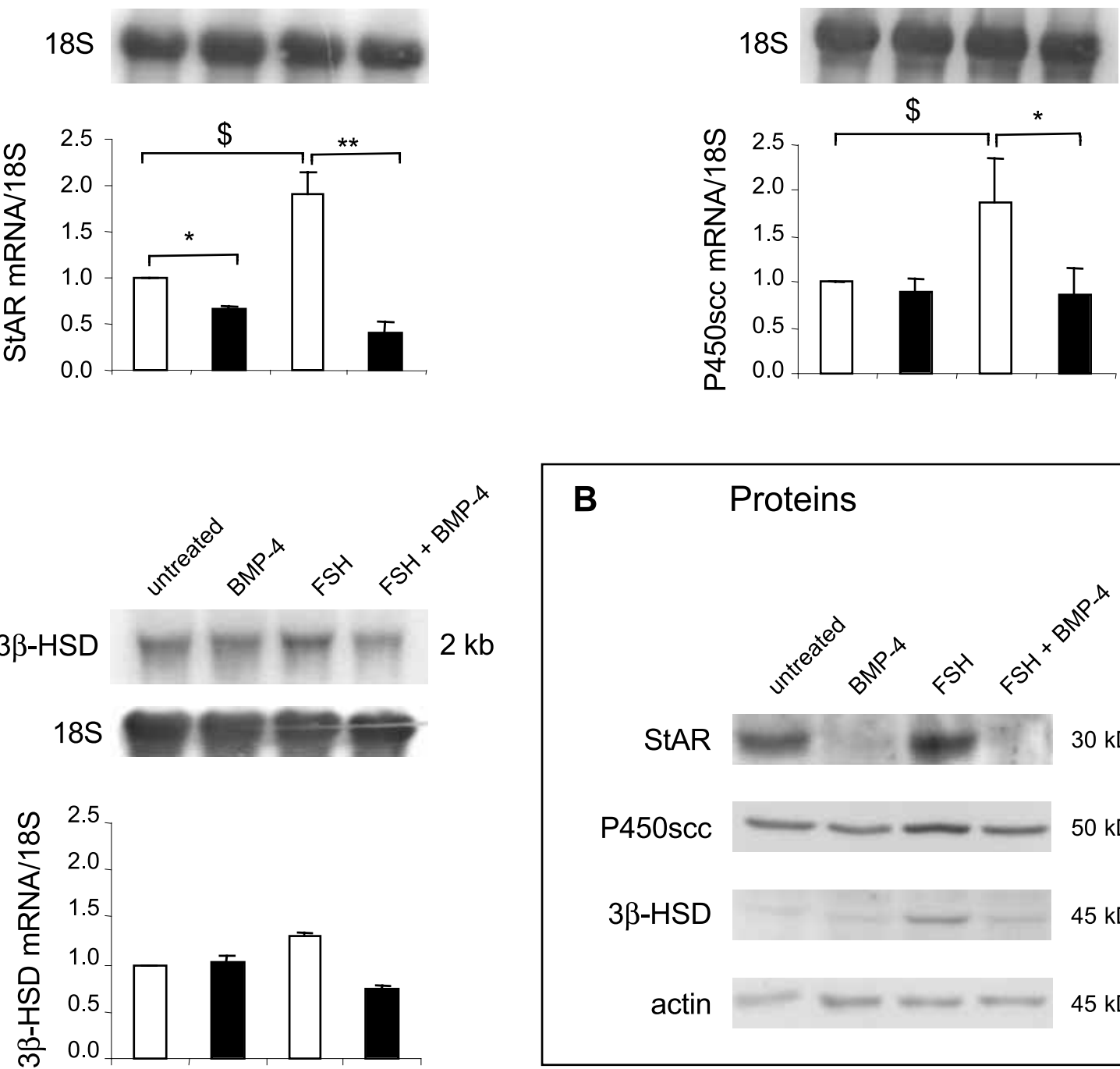

P450scc

$3 \beta-H S D$

$45 \mathrm{kDa}$

actin

$45 \mathrm{kDa}$

Figure 2 Effect of BMP-4 and FSH on expression of steroidogenic genes implicated in progesterone synthesis. GCs from small antral follicles were cultured for $72 \mathrm{~h}$ (mRNA) or $144 \mathrm{~h}$ (protein) in serum-free condition with BMP-4 $(50 \mathrm{ng} / \mathrm{ml})$ or oFSH $(5 \mathrm{ng} / \mathrm{ml})$, each alone or in combination. Each combination of treatments was tested in at least three independent experiments. (A) Representative Northern blots and quantification of StAR, P450 scc and $3 \beta$-HSD mRNA expression. Quantitated mRNA levels are expressed relative to ribosomic 18s RNA used as control. ${ }^{\star} P<0.05,{ }^{* \star} P<0.01$, BMP-4 vs untreated in basal or $\mathrm{FSH}$ condition; $\$ P<0.05$, FSH vs untreated. (B) Representative Western immunobloting analysis of GC whole cell extracts using anti-StAR, anti-P450 scc and anti-3 $\beta$-HSD specific antibodies. Actin was used as gel loading control. 


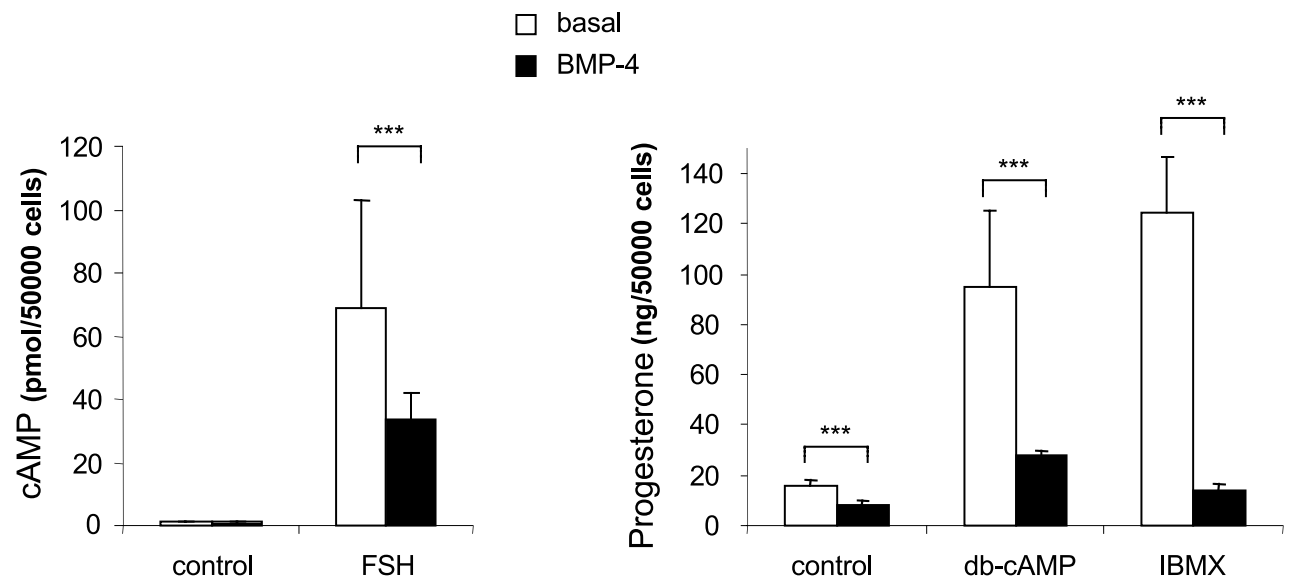

Figure 3 Effect of BMP-4 on cAMP production and activity. GCs from small antral follicles were cultured for $144 \mathrm{~h}$ in serum-free condition with or without BMP-4 $(50 \mathrm{ng} / \mathrm{ml})$. (Left-hand panel) CAMP production. At the end of the culture, GCs were incubated for $2 \mathrm{~h}$ in the presence of IBMX (2 mM, inhibitor of phosphodiesterase) alone (control) or in combination with $\mathrm{rhFSH}(50 \mathrm{ng} / \mathrm{ml})$. The amount of cAMP in the medium was measured by radioimmunoassay after acetylation of the samples. (Right-hand panel) Progesterone secretion. GC progesterone production was stimulated by culturing GCs in the presence of db-cAMP $(1 \mathrm{mM})$ or IBMX $(2 \mathrm{mM})$, each alone or in combination with BMP-4 $(50 \mathrm{ng} / \mathrm{ml})$. Each combination of treatments was tested in triplicate in each of four independent experiments. Data are shown as means \pm S.E.M. ${ }^{\star \star \star} P<0.001$, BMP-4 vs basal.

common transcription factor, SF-1 (Leers-Sucheta et al. 1997, Liu \& Simpson 1997, Sugawara et al. 1997), we next investigated the effect of BMP-4, through its signalling intermediary Smadl (Heldin et al. 1997), on SF-1 transcriptional activity.

First, we checked the ability of BMP-4 to trigger the phosphorylation and the functional activation of Smadl in ovine GCs in culture (Fig. 4). As shown in Fig. 4A, BMP-4 treatment for 30 min was able to phosphorylate Smad1. We investigated the transcriptional activity of overexpressed Smadl protein fused to the Gal4-DNA-binding domain on the Gal4-responsive element driving the luciferase gene. Stimulation with BMP-4 for $24 \mathrm{~h}$ strongly increased Smad1-dependent luciferase activity (Fig. 4B). These results indicated that Smad1, like other cell types, could act as an effector of BMP-4 action in ovine GGs.

Next, we investigated the effect of BMP-4, through Smadl, on SF-1 transcriptional activity (Fig. 5). Transient transfection experiments on ovine GCs showed that the SF-1-responsive construct pGL3 TkLH $\beta$ (Fig. 5A) activity was enhanced $(4 \cdot 5$-fold, $P<0.001)$ by overexpression of SF-1. This stimulatory effect was lowered by BMP-4 treatment $(P<0 \cdot 01)$ or Smadl expression
$(P<0.001)$ and totally abolished by Smadl expression and BMP-4 treatment. In contrast, the transcriptional activity of CREB (another cAMPdependent factor implicated in steroidogenic gene regulation), checked by the pSOM-luc construct (Fig. 5B) was not altered by overexpression of Smad-1. Thus, it appears that Smad-1 was able to specifically suppress SF-1 activity on SF-1 responsive elements.

In order to demonstrate that this Smadl antagonistic effect on SF-1 could participate in the inhibitory mechanism of steroidogenic gene expression by BMP-4, we studied the role of Smadl on StAR and P450 scc promoter activity (Fig. $5 \mathrm{C}$ and D). Overexpression of SF-1 enhanced P450 scc and StAR promoter activity and these stimulations were reduced by Smad1 co-expression $(P<0 \cdot 001)$. Interestingly, basal activity of the $\mathrm{P} 450$ scc promoter was significantly reduced by Smadl overexpression $(P<0 \cdot 05)$, suggesting a possible direct negative action of Smadl on the P450 scc promoter (Fig. 5C). The mutant P450 scc promoter in which the SF-1 binding site has been disrupted exhibited a great decrease in basal activity in comparison with the wild-type promoter and was not sensitive to SF-1 
A

\section{phospho-Smad1}

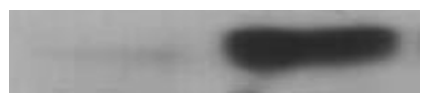

Smad1

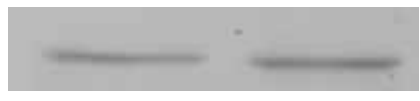

actin

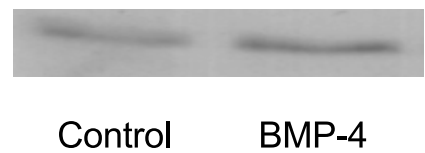

B

\section{Gal4 promoter / pGal4-Smad1}

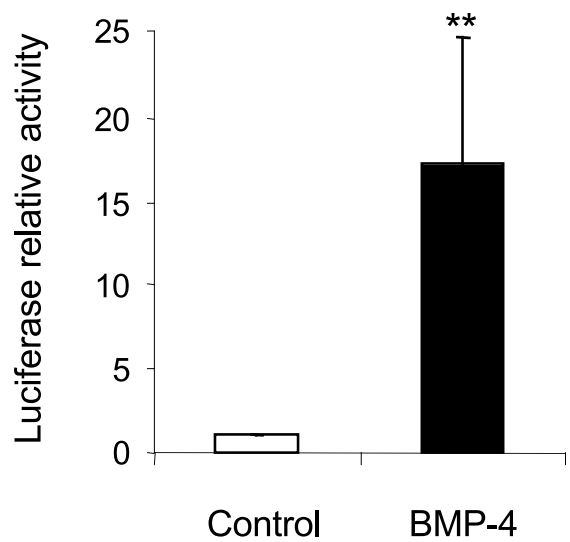

Figure 4 BMP-4 activation of the Smad1 signalling pathway. (A) Phosphorylation of Smad1 by BMP-4. After $72 \mathrm{~h}$ of culture, GCs were stimulated or not stimulated for $30 \mathrm{~min}$ with BMP-4 $(50 \mathrm{ng} / \mathrm{ml})$ in serumfree condition. Cells were lysed and subjected to Western immunoblotting using phospho-Smad1 and total Smad1 antisera. Actin was used as gel loading control. (B) Smad1 activation by BMP-4. After $72 \mathrm{~h}$ of culture, GCs were transiently cotransfected with the Gal4-responsive reporter construct (Gal4 promoter) and the plasmid expressing the Gal4 DNA-binding domain-Smad1 fusion protein (pGal4-Smad1). After transfection, GCs were incubated for $24 \mathrm{~h}$ with or without BMP-4 $(50 \mathrm{ng} / \mathrm{ml})$ in the presence of $3 \%$ fetal ovine serum, before luciferase assay. Results are expressed as luciferase activity relative to control condition. Data represent means \pm S.E.M. of measurements performed in eight independent experiments. ${ }^{\star *} P<0.01$.

overexpression. On this mutant promoter, the Smadl inhibitory action was minimized but not totally abolished $(P<0 \cdot 05)$.

\section{Discussion}

There is accumulating evidence supporting the inhibitory action of BMP molecules on progesterone production by ovarian GCs. However, most studies using the rat model have indicated that BMPs exerted their action only in FSH-induced condition. In the present study, using ovine GCs, we have confirmed the strong inhibitory action of BMP-4 on FSH-stimulated progesterone production but, in contrast to the rat, we also observed inhibition of progesterone production on its own in the absence of FSH. Based on knowledge about the implication of $\mathrm{BMP}$ in regulating ovulation rate (Galloway et al. 2000, Mulsant et al. 2001, Souza et al. 2001, Wilson et al. 2001, Hanrahan et al. 2004), this result suggests some species differences in the role of the BMP system on ovarian function between the high ovulating rodent and the low ovulating ruminant.

The objective of the present study was to explore the molecular basis by which BMP-4 exerted its inhibitory action on ovine GC basal and FSHstimulated progesterone synthesis. First, BMP-4 reduced basal and/or FSH-induced increases in mRNA and the protein levels of StAR and P450 scc, a finding consistent with the decrease in progesterone production. Secondly, BMP-4 exerted its inhibitory effect mainly downstream of cAMP signalling and to a lesser extent by decreasing FSH-dependent cAMP production. Thirdly, BMP-4 was able to activate the Smadl signalling pathway in primary ovine GCs. Fourthly, Smadl was able to inhibit the transcriptional activity of SF-1 on the LH $\beta$ promoter as well as on the StAR and P450 scc promoter. Based on these findings, we propose that part of the negative action of BMP-4 on progesterone secretion by ovine GCs would be exerted through the activation of Smadl that would inhibit the SF-1-dependent expression of StAR and P450 scc genes, leading to a decrease in progesterone synthesis activity. In FSHstimulated condition, this inhibitory mechanism would be reinforced by a decrease in FSHdependent cAMP production.

In order to appreciate the regulation of progesterone production, we examined the steadystate level of mRNA for StAR, P450 scc and $3 \beta$-HSD genes implicated in the progesterone synthesis pathway. As observed in other species (Urban et al. 1991, Pescador et al. 1997, Eimerl \& 
A LH $\beta$-Tk promoter

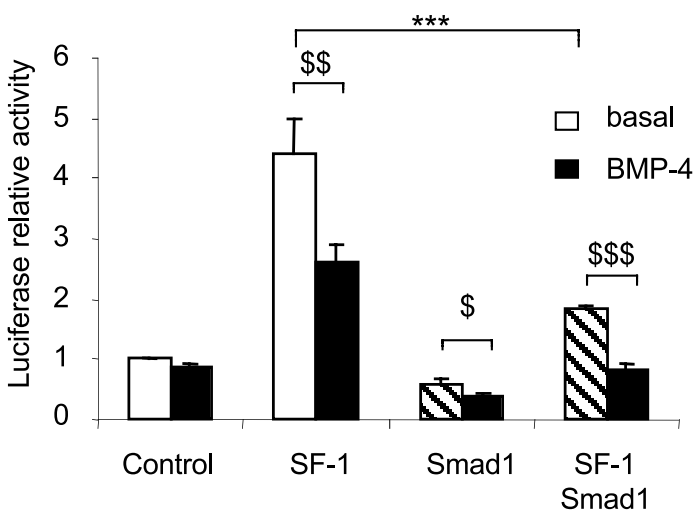

empty vector

C

P450scc promoter

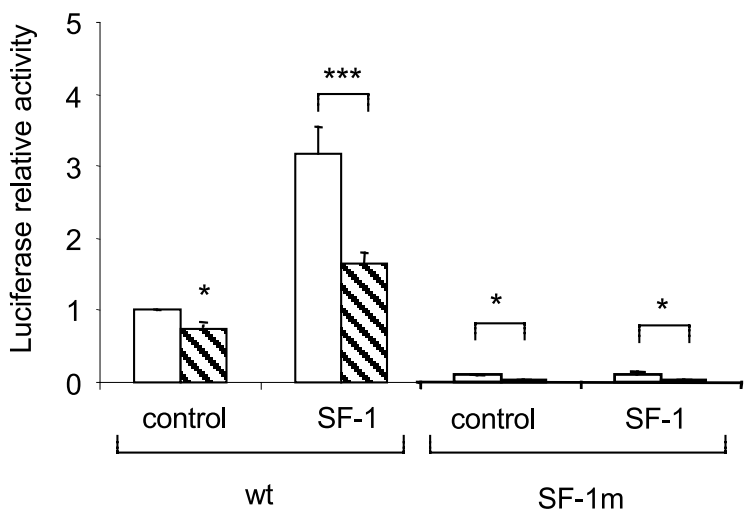

B

Somatostatin promoter

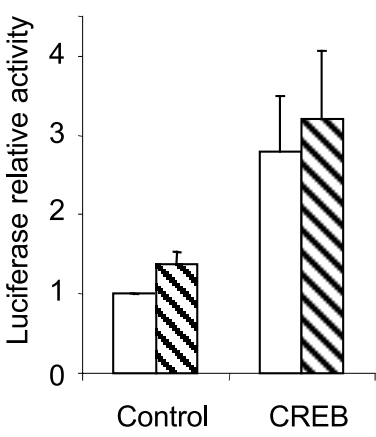

$\mathbf{\Delta}$ Smad1

D StAR promoter

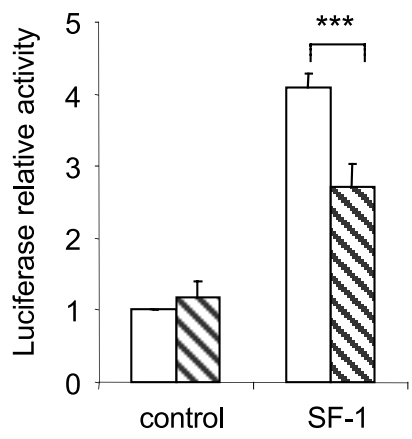

Figure 5 Effect of Smad1 expression on SF-1 and CREB transcriptional activity. GCs were cultured for $72 \mathrm{~h}$ in McCoy's 5 a medium supplemented with $3 \%$ fetal ovine serum prior to transient transfection. (A) Co-tranfection of the SF-1 responsive element of the LH $\beta$ gene promoter construct and vectors expressing or not expressing SF-1 or Smad1, each alone or in combination and treated with or without BMP-4 (50 ng/ml) for $24 \mathrm{~h}$. (B) Co-tranfection of the CREB responsive element construct of the somatostatin gene promoter and vectors expressing or not expressing CREB or Smad1, each alone or in combination and treated with oFSH $(5 \mathrm{ng} / \mathrm{ml})$ for $24 \mathrm{~h}$ to obtain transcriptional activity of CREB. (C) Co-tranfection of the wild-type (wt) P450 scc gene promoter constructs or a mutated form of the SF-1 responsive element (SF-1 m) or (D) StAR gene promoter construct and vectors expressing or not expressing SF-1 and/or Smad1. Results are expressed as luciferase activity relative to control condition (reporter construct alone). Each combination of treatments was tested in triplicate in each of four to six independent experiments. Data represent means \pm S.E.M. of measurements. $\$ P<0.05, \$ \$ P<0.01$, $\$ \$ \$ P<001$, BMP-4 vs basal, ${ }^{\star} P<0.05,{ }^{* \star *} P<0.001$, Smad1 vs empty vector.

Orly 2002), mRNA levels of StAR, P450 scc and, to a lesser extent, 3 $\beta$-HSD increased under FSH treatment. This up-regulation at the mRNA level was followed by the same regulation at the protein level. FSH-induced expression of StAR and P450 scc mRNAs and proteins was clearly down-regulated by BMP-4. These results are in agreement with those observed on FSH-stimulated 
rat GCs using BMP-15, BMP-6 or BMP-7, even if BMP-7 seems to inhibit only StAR mRNA without affecting P450 scc (Lee et al. 2001, Otsuka et al. $2001 a, b)$.

Since StAR, P450 scc and 3 $\beta$-HSD are cAMP/protein kinase A (PKA)-regulated genes (Lauber et al. 1993, Sugawara et al. 1997, Rodway et al. 1999), we have focused on the BMP-4 regulation of this signalling pathway. BMP-4 was able to inhibit the FSH-stimulated adenylate cyclase activity of GCs, as measured by cAMP production in the presence of IBMX. This result indicates a regulation of the cAMP signalling pathway by BMP-4 upstream of cAMP as previously observed for BMP-15 and BMP-6 in rat GGs (Otsuka et al. 2001a,b). BMP-15 and BMP-6 have been shown to inhibit FSH-stimulated progesterone production by two different mechanisms implying down-regulation of the $\mathrm{FSH}$ receptor expression and inhibition of adenylate cyclase activity respectively. Using RT-PCR, we were unable to demonstrate any down-regulation of FSH receptor expression by BMP-4 in ovine GGs (data not shown). In the absence of FSH, BMP-4 was without effect on cAMP production while it inhibited progesterone synthesis, supporting the hypothesis that BMP-4 is also acting downstream of cAMP. The strong inhibitory effect of BMP-4 observed on cAMP-stimulated progesterone secretion also argues in favour of this hypothesis.

Most of the transforming growth factor- $\beta / \mathrm{BMP}$ effects at the cellular level are triggered by Smad-related factors. Among the Smad family members, Smadl is considered to be a BMPresponsive Smad, because most BMPs identified to date, including BMP-2, $-4,-6,-7$ and -15 , have been shown to activate the Smadl pathway in different cell types (Candia et al. 1997, Yamamoto et al. 1997, Macias-Silva et al. 1998, Henningfeld et al. 2000, Moore et al. 2003). Based on this fact, we investigated whether BMP-4 activates the Smadl pathway in primary ovine GGs. Treatment of cells with BMP-4 caused a clear increase (i) in the level of phosphorylated Smadl as determined by immunoblotting and (ii) in Smadl transcriptional ability as shown by transient tranfection experiments. Hence Smadl can transduce the BMP-4 signal in ovine GCs. Although the Smad pathway is the main canonical pathway for BMP ligands, there is much evidence on the activation of alternative pathways, particularly the p38 kinase of the MAPK family in various cell types (for a review see Nohe et al. 2004). In agreement, we have observed a weak increase in phosphorylated p38 MAPK under BMP-4 treatment in ovine GGs (Pierre et al. 2002). However, the inhibition of p38 phosphorylation in vitro by a specific inhibitor (SB203580) had no effect on BMP-4 suppression of progesterone production (A Pierre, unpublished data), suggesting that activation of the p38 MAPK pathway by BMP-4 cannot be implicated in the mechanism of progesterone inhibition.

The ability of BMP-4 to regulate post-cAMP steps and to activate the Smadl factor led us to hypothesize the existence of functional interactions between the transcription factors of these two pathways in the regulation of steroidogenic gene expression. To date, no Smad binding element (SBE) has been described on the regulatory region of StAR or P450 scc or 3 $\beta$-HSD genes. Our present transient transfection experiments did not detect any effect of Smadl on the basal activity of the human StAR proximal promoter. In contrast, basal activity of the P450 scc proximal promoter appeared to be sensitive to Smadl overexpression even in the context of a disrupted SF-1-binding site, indicating a possible direct inhibitory action of Smadl on the P450 scc promoter. Alternatively, cAMP/PKA-activated transcription factors such as CREB and SP-1, known to regulate genes of the steroidogenic pathway (Mukherjee et al. 1996, Leers-Sucheta et al. 1997, Liu \& Simpson 1997, Sugawara et al. 2000) have also been shown to functionally interact with Smad factors. Indeed, Warner et al. (2003) recently demonstrated that phosphorylated CREB could be associated through the CREB-binding protein (CBP) with a Smad2 SBE-bound transcriptional complex. Moreover, SP-1 can co-operate with Smad3 to regulate the $\alpha 2$ (I) collagen promoter gene (Poncelet \& Schnaper 2001) and with Smad2, 3 and 4 to control the promoter of the p15 ${ }^{\text {Ink4B }}$ gene (Feng et al. 2000). Nevertheless, FSH-activated CREB did not cooperate with Smadl to drive the CREB-dependent somatostatin promoter gene in our transient transfection experiments with ovine GCs. In contrast, we have clearly demonstrated that the transcriptional activity of SF-1, another factor implicated in basal as well as in cAMP-induced regulation of steroidogenic genes (Liu \& Simpson 1997, Sugawara et al. 1997), was altered by Smad1. 
This is the first demonstration of a functional negative crosstalk between Smad factors and SF-1 in any cell type. Such a negative alteration of a transcription factor activity by Smad factors has been described only for the nuclear factor $\mathrm{\kappa B}$ $(\mathrm{NF} \kappa \mathrm{B})$ (DiChiara et al. 2000). The inhibitory mechanism implies a competitive interaction between Smad2 and NFкB mediated by the transcriptional coactivator CBP, without Smad2/ $\mathrm{NF \kappa B}$ direct interaction. Of note, in our model, co-immunoprecipitation experiments with overexpressed Smadl and SF-1 failed to detect any direct interaction between Smadl and SF-1 (A Pierre, data not shown). Hence, one can hypothesize about the possible implication of an intermediary factor such CBP, known to interact with Smad factors (Pouponnot et al. 1998) and SF-1 (Monte et al. 1998). Further experiments are needed to validate this hypothesis on the inhibitory mechanism of Smadl on SF-1 in the context of GCs, and to study the mechanism that underlies this inhibition.

Nevertheless, the inhibiting action of Smadl on $\mathrm{SF}-1$, checked by the $\mathrm{SF}-1$ responsive element of the LH $\beta$ subunit promoter gene, occurs also on the SF-1-dependent response of human StAR and P450 scc promoter constructs. These results need to be considered together with the observed inhibition of StAR and P450 scc mRNA expression by BMP-4. Therefore, one may hypothesize that part of the BMP-4-induced inhibition of StAR and P450 scc genes expression, and ultimately progesterone secretion, would pass through a Smadl-dependent inhibition of SF-1 activity. Since SF-1 is a key regulator of $\mathrm{GC}$ differentiation, our present data reinforce the hypothesis that BMP factors control ovarian follicle development in delaying GC differentiation.

\section{Acknowledgements}

We thank A Nicolle for excellent technical assistance. We also thank F Dupont and the staff of the ovine experimental unit in Nouzilly for their collaboration in the experimental design. This work was supported in part by the French Ministère de la Recherche 'Technologie pour la santé' ACI grant 'REGLO: REGuLation de l'Ovulation'. A P was supported by a French fellowship from the 'Région Centre'.

\section{References}

Campbell BK, Scaramuzzi RJ \& Webb R 1996 Induction and maintenance of oestradiol and immunoreactive inhibin production with FSH by ovine granulosa cells cultured in serum-free media. Journal of Reproduction and Fertility 106 7-16.

Candia AF, Watabe T, Hawley SH, Onichtchouk D, Zhang Y, Derynck R, Niehrs C \& Cho KW 1997 Cellular interpretation of multiple TGF-beta signals: intracellular antagonism between activin/BVgl and BMP-2/4 signaling mediated by Smads. Development 124 4467-4480.

DiChiara MR, Kiely JM, Gimbrone MA Jr, Lee ME, Perrella MA \& Topper JN 2000 Inhibition of E-selectin gene expression by transforming growth factor beta in endothelial cells involves coactivator integration of Smad and nuclear factor kappaB-mediated signals. Fournal of Experimental Medicine 192 695-704.

Dong J, Albertini DF, Nishimori K, Kumar TR, Lu N \& Matzuk MM 1996 Growth differentiation factor-9 is required during early ovarian folliculogenesis. Nature 383 531-535.

Drummond AE, Le MT, Ethier JF, Dyson M \& Findlay JK 2002 Expression and localization of activin receptors, Smads, and beta glycan to the postnatal rat ovary. Endocrinology 143 1423-1433.

Eimerl S \& Orly J 2002 Regulation of steroidogenic genes by insulin-like growth factor-1 and follicle-stimulating hormone: differential responses of cytochrome P450 side-chain cleavage, steroidogenic acute regulatory protein, and 3 beta-hydroxysteroid dehydrogenase/isomerase in rat granulosa cells. Biology of Reproduction 67 900-910

Elvin JA, Yan C \& Matzuk MM 2000 Oocyte-expressed TGF-beta superfamily members in female fertility. Molecular and Cellular Endocrinology 159 1-5.

Fabre S, Pierre A, Pisselet C, Mulsant P, Lecerf F, Pohl J, Monget P \& Monniaux D 2003 The Booroola mutation in sheep is associated with an alteration of the bone morphogenetic protein receptor-IB functionality. Fournal of Endocrinology 177 435-444.

Feng XH, Lin X \& Derynck R 2000 Smad2, Smad3 and Smad4 cooperate with $\mathrm{Spl}$ to induce $\mathrm{p} 15(\mathrm{Ink} 4 \mathrm{~B})$ transcription in response to TGF-beta. EMBO fournal 19 5178-5193.

Galloway SM, McNatty KP, Cambridge LM, Laitinen MP, Juengel JL, Jokiranta TS, McLaren RJ, Luiro K, Dodds KG, Montgomery GW, Beattie AE, Davis GH \& Ritvos O 2000 Mutations in an oocyte-derived growth factor gene (BMP15) cause increased ovulation rate and infertility in a dosage-sensitive manner. Nature Genetics 25 279-283.

Gizard F, Lavallee B, DeWitte F, Teissier E, Staels B \& Hum DW 2002 The transcriptional regulating protein of $132 \mathrm{kDa}$ (TReP-132) enhances P450 scc gene transcription through interaction with steroidogenic factor-1 in human adrenal cells. Fournal of Biological Chemistry 277 39144-39155.

Hanrahan JP, Gregan SM, Mulsant P, Mullen M, Davis GH, Powell R \& Galloway SM 2004 Mutations in the genes for oocyte-derived growth factors GDF9 and BMP15 are associated with both increased ovulation rate and sterility in Cambridge and Belclare sheep (Ovis aries). Biology of Reproduction 70 900-909.

Heldin GH, Miyazono K \& ten Dijke P 1997 TGF-beta signalling from cell membrane to nucleus through SMAD proteins. Nature $390465-471$

Henningfeld KA, Rastegar S, Adler G \& Knochel W 2000 Smad1 and Smad4 are components of the bone morphogenetic protein- 4 (BMP-4)-induced transcription complex of the Xvent-2B promoter. Fournal of Biological Chemistry 275 21827-21835.

Ishida W, Hamamoto T, Kusanagi K, Yagi K, Kawabata M, Takehara K, Sampath TK, Kato M \& Miyazono K 2000 Smad6 is a Smad1/5-induced smad inhibitor. Characterization of bone morphogenetic protein-responsive element in the mouse Smad6 promoter. Fournal of Biological Chemistry 275 6075-6079. 
Khamsi F, Roberge S, Yavas Y, Lacanna IC, Zhu X \& Wong J 2001 Recent discoveries in physiology of insulin-like growth factor- 1 and its interaction with gonadotropins in folliculogenesis. Endocrine 16 151-165.

Lauber ME, Kagawa N, Waterman MR \& Simpson ER 1993 cAMP-dependent and tissue-specific expression of genes encoding steroidogenic enzymes in bovine luteal and granulosa cells in primary culture. Molecular and Cellular Endocrinology 93 227-233.

Le Bellego F, Pisselet C, Huet C, Monget P \& Monniaux D 2002 Laminin- $\alpha 6 \beta 1$ integrin interaction enhances survival and proliferation and modulates steroidogenesis of ovine granulosa cells. Fournal of Endocrinology 172 45-59.

Lee WS, Otsuka F, Moore RK \& Shimasaki S 2001 Effect of bone morphogenetic protein-7 on folliculogenesis and ovulation in the rat. Biology of Reproduction $65994-999$.

Leers-Sucheta S, Morohashi K, Mason JI \& Melner MH 1997 Synergistic activation of the human type II 3 beta-hydroxysteroid dehydrogenase/delta5-delta4 isomerase promoter by the transcription factor steroidogenic factor-1/adrenal 4-binding protein and phorbol ester. Fournal of Biological Chemistry 272 7960-7967.

Liu Z \& Simpson ER 1997 Steroidogenic factor 1 (SF-1) and SP1 are required for regulation of bovine CYP11A gene expression in bovine luteal cells and adrenal Y1 cells. Molecular Endocrinology 11 127-137.

Macias-Silva M, Hoodless PA, Tang SJ, Buchwald M \& Wrana JL 1998 Specific activation of Smadl signaling pathways by the BMP7 type I receptor, ALK2. Fournal of Biological Chemistry $\mathbf{2 7 3}$ 25628-25636.

Monget P, Fabre S, Mulsant P, Lecerf F, Elsen JM, Mazerbourg S, Pisselet C \& Monniaux D 2002 Regulation of ovarian folliculogenesis by IGF and BMP system in domestic animals. Domestic Animal Endocrinology 23 139-154.

Monte D, DeWitte F \& Hum DW 1998 Regulation of the human $\mathrm{P} 450$ scc gene by steroidogenic factor 1 is mediated by CBP/p300. Fournal of Biological Chemistry 273 4585-4591.

Moore RK, Otsuka F \& Shimasaki S 2003 Molecular basis of bone morphogenetic protein-15 signaling in granulosa cells. Fournal of Biological Chemistry 278 304-310.

Mukherjee A, Park-Sarge OK \& Mayo KE 1996 Gonadotropins induce rapid phosphorylation of the $3^{\prime}, 5^{\prime}$-cyclic adenosine monophosphate response element binding protein in ovarian granulosa cells. Endocrinology 137 3234-3245.

Mulsant P, Lecerf F, Fabre S, Schibler L, Monget P, Lanneluc I, Pisselet C, Riquet J, Monniaux D, Callebaut I, Cribiu E, Thimonier J, Teyssier J, Bodin L, Cognie Y, Chitour N \& Elsen JM 2001 Mutation in bone morphogenetic protein receptor-IB is associated with increased ovulation rate in Booroola merino ewes. PNAS 98 5104-5109.

Nohe A, Keating E, Knaus P \& Petersen NO 2004 Signal transduction of bone morphogenetic protein receptors. Cellular Signalling 16 291-299.

Otsuka F, Yao Z, Lee T, Yamamoto S, Erickson GF \& Shimasaki S 2000 Bone morphogenetic protein-15. Identification of target cells and biological functions. Fournal of Biological Chemistry 275 39523-39528.

Otsuka F, Moore RK \& Shimasaki S 2001 $a$ Biological function and cellular mechanism of bone morphogenetic protein-6 in the ovary. Fournal of Biological Chemistry 276 32889-32895.

Otsuka F, Yamamoto S, Erickson GF \& Shimasaki S $2001 b$ Bone morphogenetic protein-15 inhibits follicle-stimulating hormone (FSH) action by suppressing FSH receptor expression. Fournal of Biological Chemistry 276 11387-11392.

Pearson KL, Hunter T \& Janknecht R 1999 Activation of Smadl-mediated transcription by p300/CBP. Biochimica et Biophysica Acta 1489 354-364.
Pescador N, Houde A, Stocco DM \& Murphy BD 1997

Follicle-stimulating hormone and intracellular second messengers regulate steroidogenic acute regulatory protein messenger ribonucleic acid in luteinized porcine granulosa cells. Biology of Reproduction 57 660-668.

Pierre A, Fabre S, Pisselet C, Monniaux D \& Monget P 2002 Rôle des bone morphogenetic proteins (BMPs) dans la fonction ovarienne chez la brebis. Annals of Endocrinology 63114.

Poncelet AC \& Schnaper HW 2001 Spl and Smad proteins cooperate to mediate transforming growth factor-beta 1-induced alpha 2(I) collagen expression in human glomerular mesangial cells. Fournal of Biological Chemistry 276 6983-6992.

Pouponnot C, Jayaraman L \& Massague J 1998 Physical and functional interaction of SMADs and p300/CBP. Foumal of Biological Chemistry 273 22865-22868.

Richards JS \& Hedin L 1988 Molecular aspects of hormone action in ovarian follicular development, ovulation, and luteinization. Annual Review of Physiology 50 441-463.

Rodway MR, Swan CL, Gillio-Meina C, Crellin NK, Flood PF \& Chedrese PJ 1999 Regulation of steroidogenesis in jc-410, a stable cell line of porcine granulosa origin. Molecular and Cellular Endocrinology 148 87-94.

Saumande J 1991 Culture of bovine granulosa cells in a chemically defined serum-free medium: the effect of insulin and fibronectin on the response to FSH. Fournal of Steroid Biochemistry and Molecular Biology 38 189-196.

Shimasaki S, Zachow RJ, Li D, Kim H, Iemura S, Ueno N, Sampath K, Chang RJ \& Erickson GF 1999 A functional bone morphogenetic protein system in the ovary. PNAS 96 $7282-7287$.

Souza CJ, MacDougall C, Campbell BK, McNeilly AS \& Baird DT 2001 The Booroola (FecB) phenotype is associated with a mutation in the bone morphogenetic receptor type $1 \mathrm{~B}$ (BMPR1B) gene. Fournal of Endocrinology 169 R1-R6.

Souza CJ, Campbell BK, McNeilly AS \& Baird DT 2002 Effect of bone morphogenetic protein 2 (BMP2) on oestradiol and inhibin A production by sheep granulosa cells, and localization of BMP receptors in the ovary by immunohistochemistry. Reproduction 123 363-369.

Sugawara T, Holt JA, Kiriakidou M \& Strauss JF 3rd 1996 Steroidogenic factor 1-dependent promoter activity of the human steroidogenic acute regulatory protein (StAR) gene. Biochemistry 35 9052-9059.

Sugawara T, Kiriakidou M, McAllister JM, Kallen CB \& Strauss JF 3rd 1997 Multiple steroidogenic factor 1 binding elements in the human steroidogenic acute regulatory protein gene $5^{\prime}$-flanking region are required for maximal promoter activity and cyclic AMP responsiveness. Biochemistry 36 7249-7255.

Sugawara T, Saito M \& Fujimoto S 2000 Spl and SF-1 interact and cooperate in the regulation of human steroidogenic acute regulatory protein gene expression. Endocrinology 141 2895-2903.

Urban RJ, Garmey JC, Shupnik MA \& Veldhuis JD 1991 Follicle-stimulating hormone increases concentrations of messenger ribonucleic acid encoding cytochrome $\mathrm{P} 450$ cholesterol side-chain cleavage enzyme in primary cultures of porcine granulosa cells. Endocrinology 128 2000-2007.

Val P, Lefrancois-Martinez AM, Veyssiere G \& Martinez A 2003 SF-1 a key player in the development and differentiation of steroidogenic tissues. Nuclear Receptor 18 (url: www.nuclear-receptor.com/content/1/1/8).

Vitt UA, Hayashi M, Klein C \& Hsueh AJ 2000 Growth differentiation factor-9 stimulates proliferation but suppresses the follicle-stimulating hormone-induced differentiation of cultured granulosa cells from small antral and preovulatory rat follicles. Biology of Reproduction 62 370-377.

Warner DR, Pisano MM \& Greene RM 2003 Nuclear convergence of the TGFbeta and cAMP signal transduction pathways in 
murine embryonic palate mesenchymal cells. Cellular Signalling $\mathbf{1 5}$ 235-242.

Wilson T, Wu XY, Juengel JL, Ross IK, Lumsden JM, Lord EA, Dodds KG, Walling GA, McEwan JC, O'Connell AR, McNatty KP \& Montgomery GW 2001 Highly prolific Booroola sheep have a mutation in the intracellular kinase domain of bone morphogenetic protein IB receptor (ALK-6) that is expressed in both oocytes and granulosa cells. Biology of Reproduction $\mathbf{6 4}$ 1225-1235.

Winters TA, Hanten JA \& Veldhuis JD 1998 In situ amplification of the cytochrome P-450 cholesterol side-chain cleavage enzyme mRNA in single porcine granulosa cells by IGF-1 and FSH acting alone or in concert. Endocrine 9 57-63.
Xu J, Oakley J \& McGee EA 2002 Stage-specific expression of Smad2 and Smad3 during folliculogenesis. Biology of Reproduction 66 1571-1578.

Yamamoto N, Akiyama S, Katagiri T, Namiki M, Kurokawa T \& Suda T 1997 Smad1 and smad5 act downstream of intracellular signalings of BMP-2 that inhibits myogenic differentiation and induces osteoblast differentiation in C2C12 myoblasts. Biochemical and Biophysical Research Communications 238 574-580.

Received 20 August 2004

Accepted 21 September 2004 